مجلة دراسات في المناهج وطرق التدريس، الترقيم الدولي (ISSN 2535-213X)/ العدد 245 (2019م)

\title{
Challenges of Implementing Montessori English Teaching Model in Saudi Arabian Elementary Schools
}

Dr. waleed Al-Abiky

\begin{abstract}
:
Montessori English Teaching Model (METM) is a unique way of instruction that uses specifically designed learning settings and approaches to nurture students' intrinsic desire to learn. English achievements for Saudi students have been for long very low. The current study aimed to investigate the real challenges of implementing Montessori English Teaching Model in Saudi Arabian elementary schools. Qualitative method, namely focus group discussion, was used. Four purposive focus groups with different educational positions and experiences were formulated, namely school supervisors (SS), school principals (SP), English teachers (ET), and English curriculum specialists (ES). The major findings of the study were that1) major challenges existed for implementing the METM in Saudi elementary schools, 2) the challenges concentrated on four categories: educational context, work ethics and environment, nature of teachers and students, and social aspects, and 3) agreements on some of the sub-themes fluctuated. Recommendations for further investigations are made for interested and educational personnel.
\end{abstract}

Keywords: Montessori, English teaching model, Saudi elementary school, challenges, Saudi Arabia. 
مجلة دراسات في المناهج وطرق التدريس، الترقيم الدولي (ISSN 2535-213X)/ العدد 245 (2019م)

\section{Challenges of Implementing Montessori English Teaching Model in Saudi Arabian Elementary Schools}

\section{Introduction:}

The traditional methods of schooling have for long failed to accommodate the various types of students and fulfill the early adolescent students' development needs which ultimately resulted in ' struggling students and failing schools' (McDurham, 2011, p. 5). Montessori model provides an alternative way of learning and more creative methods of teaching English taking into accounts the students' strengths, independence, and uninterrupted work environment.

Montessori is a unique educational system that ensures a safe and supportive learning environment for all students. Montessori model has been described as self-activated, multicultural, collaborative and accommodating (Stapleton, 2014; Ghaffari, Kashkouli, \& Sadighi, 2017). Maria Montessori, an Italian physician, was first to develop the model and started the first Montessori school in 1907 to serve students who were economically disadvantaged, as well as children with less achievements potentials (Pickering, 1992). Nowadays, Montessori schools are largely considered as high-quality education providers with long lasting impacts on students' early- and middle-school years (Dearing, McCartney \& Taylor, 2009; Vandell et al., 2010).

Moreover, Montessori elementary schools became more prevalent in the 1990s, with middle and secondary schools slowly emerging (Seldin, 2002-03). Montessori is an educational model that promises better results, 
مجلة دراسات في المناهج وطرق التدريس، الترقيم الدولي (ISSN 2535-213X)/ العدد 245 (2019م)

if done properly, and would ensure a fulfilling level of human development in different aspects such as cognitive, social, and emotional.

The current study investigated the challenges of implementing the Montessori English Teaching Model (METM) specifically designed for students at young age in Saudi Arabian elementary schools taking into account the ways and variances of students' linguistic growth and schools' settings.

\section{Montessori English Teaching Model:}

Montessori philosophy and practice is unique and differs in many ways from other educational practices such as the one in Saudi Arabia. First, Montessori practice and approach to English teaching and learning drives from Maria Montessori when she focused on the stages of human minds and development. Maria stated that the children at the young school age have sponge-like brains in which children during this time have the ability to easily absorb the information and recall them. She called this stage 'an absorbent mind stage' (Montessori, 1949). During this stage, students can learn any language and assimilate any culture with ease and pace (Gutek, 2004).

Moreover, Montessori schools' settings are based on some principals that help to foster the learning of English. The English language classrooms in Montessori schools are organized to pave the way for more meaningful collaboration and interaction in a multicultural environment which facilitates English learning to happen. Chomsky stressed the importance of social interaction in a diverse environment to help learners in their process of acquisition (Lightbown \& Spada, 2013). 
According to Montessori principals, students' processes of English acquisition and accumulative knowledge are greatly supported by the learning environment which would ultimately help students to increase their academic achievement (Ghaffari, Kashkouli, \& Sadighi, 2017). The Montessori settings positively influence students and advance their development of independence and self-exploration at their most (Lillard, 2013; Kay1l1, 2018).

Working in and with a multi-age group is one of the METM principles and approaches to English teaching (American Montessori Society, 2017; Hainstock,

1997). Working in and with multi-age groups, learning moments and teaching possibilities would soar; younger and even older students would learn from each other by imitation, observation, and meaningful discussion (Lillard, 2005).

In the multi-age groups, the groups are flexible and might differ which permit students to find interest in the work of other groups or individuals. In addition, young adolescence learn from the various activities that the cooperative and collaborative learning environments offer in the classrooms (McDurham, 2011). As the time progress, Montessori students would accept diversity, variances and not to fear interaction or even cooperation with others. As a result, students would smoothly progress at a higher educational level (Mckenzie, 2007).

\section{English Teaching in Saudi Arabia Elementary School:}

\section{A call for reform}

Education in Saudi Arabia has recently undergone fundamental changes, improvements and endless efforts of reforms in many aspects. However, not all of these efforts have made a satisfactory success. As 
regards to English teaching as a core school subject, students' achievements are way below expectations (Ashraf, 2018). Despite the fact that English has been around in elementary schools in Saudi Arabia for many years now, Saudi students are still below average in regards to their English proficiency and unable to carry even a simple and short conversation (Alshumaimeri, 2003). For instance, the scores of Saudi test takers in many of the English standardized tests have been very low (Author, 2019).

Until recently, the literature has documented some real, but scattered factors for getting such results. For instance, Al shlowiy (2014) argued that the teaching methods in Saudi Arabia have greatly changed and widely varied recently. However, English teaching in Saudi Arabia is distracted due to the lack of motivation from teachers and students, lack of innovative instruction, and the overwhelm indulgence in social media and other attractive sources outside schools.

Fareh (2010), moreover, pointed out some reasons and causes for Saudi students' low English achievement scores such as ineffective instruction that is mainly teachers-centered rather than students-centered, untrained or improperly trained English teachers, and teaching monotony. Moreover, lack of exposure to English natives or even native-like settings has also been a reason for such achievements (Author, 2019).

\section{Significant of the study:}

Recent studies have emphasized the rapid expansion of Montessori educational system and programs because of its unique approach in teaching and learning (Lopata, Wallace \& Finn, 2005) in which students are integrated into classrooms activities and making them more engaged in classroom activities to achieve the desired educational outcomes (Kuh, 
2009). Active interaction is a key element in the Montessori educational system while EFL students are always encouraged to interact and get deeply involved in co- and extra-curricular activities in their hosting schools. Kuh (2009) emphasized two major facets of these interactions: a) in-class (or academic) engagement, and b) out-of-class engagement in educationally relevant activities, both of which are important to students' success and acquisition. The two facets are considered and taken into action in Montessori schools.

In Saudi Arabia, however, education is largely operated and controlled by the Ministry of Education in which all elementary schools around the country teach the same curricula, and probably in the same way of teaching. In Saudi Arabia, there is none or may be a few, if any, school that follows Montessori model in teaching and learning.

The current study tried to explore some of the real challenges of implementing the METM in Saudi Arabian elementary schools' English subjects. Voices were heard and thoughts were discussed for future hope to overcome those challenges.

\section{Research Problem:}

Despite the effort, money and time spent in developing English teaching and learning in Saudi Arabia, students' English progress and achievement are still below the desired level of proficiency. Saudi students' scores in many English standardized testing matrixes have been low (Author, 2019), which is seen as an indicator that something is wrong and things need to change.

Moreover, students at the upper of elementary schools are in a transition period from childhood to adolescence which is usually 
challenging for many educators; this period is considered the "turning point" for the educational and social lives and well-being for theme (McDurham, 2011). However, current English as a core subject in the elementary schools in Saudi Arabia fail to provide a smooth transition that fulfills the students' needs of emotional, social and linguistics development (Goodenow, 1993).

\section{Research Questions:}

The current study attempted to answer the following questions:

1) What are the challenges of implementing the Montessori elementary schools' model of English teaching and learning in Saudi Arabia?

2) What are the differences in regards to these challenges between members of the focus group?

\section{Literature Review}

There is a small, but growing body, of educational literature that mainly focuses on METM at elementary school. This study served to close the gap, and the challenges of implementing the model in a different setting was addressed.

In their study, Ansari \& Winsler (2014) indicated that Montessori and traditional education programs reportedly differ from each other in several ways such as the scope of curricula, physical environment, and instructional methodology. Instructionally, moreover, Montessori programs use manipulative materials in classroom settings as instructional methodologies, whereas traditional classrooms sometimes use materials as teacher presentation aids.

Moreover, Rathunde \& Csikszentmihalyi (2005) investigated the perceptions of 290 middle schools students in Montessori and traditional 
مجلة دراسات في المناهج وطرق التريس، الترقيم الدولي (ISSN 2535-213X)/ العدد 245 (2019م)

schools regarding the social contexts, teachers and school environment. By using quantitative methods, mainly surveys, they found that 1) Montessori students had more positive attitudes towards their schools than students in the traditional middle schools; and 2) the Montessori middle schools students considered their classmates as friends during school time.

More importantly, current studies show that there are significant differences in students' progress and achievements between students in traditional and Montessori schools. For instance, several recent studies show that students enrolled in Montessori classrooms - especially during the pre-school years (Kayili \& Ari, 2011; Lillard, 2012; Lillard \& ElseQuest, 2006) and even during the later years in elementary school, middle, and high school demonstrate greater gains in academic, socio-emotional, and behavioral skills than children enrolled in more conventional programs (Dohrmann, Nishida, Gartner, Lipsky, \& Grimm, 2007; Lillard \& ElseQuest, 2006; Rathunde \& Csikszentmihalyi, 2005).

In his study contrasting the $7^{\text {th }}$ and $8^{\text {th }}$ grades students' academic progress and achievement in Montessori and tradition schools, McDurham (2011) found that Montessori students in both grades had better learning progress and higher levels of achievements than their peers in traditional schools especially in reading and math. McDurham, moreover, concluded that Montessori schools' model produces more favorable learning outcomes when compare to students in the traditional schools.

However, a few studies looked at the challenges and difficulties of implementing the METM in elementary schools. Duckworth (2006) spotted the lights on the teacher as a possible challenge for implementing Montessori in schools. The role of Montessori teacher is not to lead the 
teaching and learning because it is a disruption of the learning flow. As a result, teachers should act more wisely in regards to the correction of students' errors and using students' strengths, knowledge and critical thinking to discover their mistakes, think about them and fix them.

The Montessori curriculum and its designed activities are also a big challenge. Marshall (2017) differentiated the Montessori curriculum from the traditional one. Unlike in traditional settings, students in Montessori are independent and friendly in nature with many designed interactions. As a result, the ultimate aim of Montessori curriculum is to prepare students for social life and to do their best in the classroom.

In addition, Christensen (2018) considered Montessori unique instruction as a big challenge for teachers in traditional schools to follow. Children in Montessori settings, for instance, learn naturally and by selfdiscovery rather than by traditional prompt methods of instruction. As a result, little support and guidance, if any, is given to students in Montessori which most, if not all, teachers in the traditional methods have never experienced or even are familiar with it.

Consequently, Lillard (2018) believed that teacher preparation in Montessori is a big challenge which requires a different type of preparation in which Montessori depends on the training of teachers rather than education. In fact, Cossentino (2009) believed that to prepare a teacher to become a Montessori teacher requires a deep and serious transformation in the way of looking at how young students learn and when human development occurs.

\section{Methods:}

The current study investigated the challenges of implementing METM in Saudi Arabian elementary schools and educational systems. 
Qualitative method, namely focus group discussion, was used to conduct the study. The focus group method is an exploratory technique to collect qualitative data through interactive group discussion allowing the participants to discuss the themes freely and in more depth (Beyea and Nicoll, 2000).

Unlike interviews, focus groups as a research method allows more interaction and deep discussion and reflection to take place in a natural friendly setting in which each participant is encouraged to talk freely and express their perceptions, feelings, and experiences and share some concerns or even some sensitive issues (Tracy et al., 2006).

To achieve the study goals, four small-size focus groups in which each group consisted of '5' participants were formulated. Open-ended questions about particular topics were introduced for each group to stimulate more interaction and discussion (Krueger \& Casey, 2000), and, thus, collect more qualitative data.

\section{Participants}

To investigate the challenges of implementing Montessori English teaching model in Saudi Arabian Education, four purposive focus groups were formulated with different educational positions and experiences, namely school supervisors (SS), school principals (SP), English teachers (ET), and English curriculum specialists (ES). There were two essential reasons for such formulation of the groups. First, those individuals were not only familiar with the reality of English teaching and learning in Saudi Arabia but also responsible for English outcomes and achievements in the schools. Second, each member of the group has a rich and different view and perspective of English teaching and learning which would generate 
more topics to discuss and, as a result, encourage others to speak and comment.

In the current study, purposive sampling was the method used to collect the data in which three criteria were required to participate in the study. Only participants meeting those criteria were invited to the focus group: 1) they all had been working in their educational position for at least three years or above, 2) they all were familiar with Montessori schools and teaching model, and 3) they all have been abroad for school and studying. The total number of participants were (20) formulating the focus groups. Table 1 shows the participants' demographic characteristics. Table 1:

Demographic Characteristics of Participants

\begin{tabular}{cccc}
\hline Characteristics & $\mathrm{N}$ & Percentage & Rank \\
\hline Position: & $(\mathrm{n}=20)$ & & \\
Schools Supervisors & 4 & 20 & $2^{\text {nd }}$ \\
English Specialists & 6 & 30 & $1^{\text {st }}$ \\
Schools' Principals & 4 & 20 & $2^{\text {nd }}$ \\
English Teachers & 6 & 30 & $1^{\text {st }}$ \\
& & & \\
Year of Experience: & & & $3^{\text {rd }}$ \\
$>5$ & 4 & 20 & $1^{\text {st }}$ \\
$6-10$ & 9 & 45 & $2^{\text {nd }}$ \\
10 & 7 & 35 & $2^{\text {nd }}$ \\
Gender: & & 30 & $1^{\text {st }}$ \\
Female & 7 & 70 & \\
Male & 13 & &
\end{tabular}

\section{1}




\section{Data Collection:}

Before the discussion of each focus group began, the mediator (researcher) confirmed the consent form for each participant in the focus group explaining the purpose of the study, the risks and rewards, rules of the discussion, their rights to participate or withdraw and the confidentiality of data. In addition, the discussion of each focus group was recorded by audio recording devices, and transcribed with underlining themes. To ensure the data validity, moreover, the discussion was not only recorded but also the recurring themes and ideas of discussion were presented to the participants to elaborate more on the topics and eliminate any possible misinterpretation of thoughts and ideas.

Moreover, before discussing the challenges of implementing Montessori schools model, each discussion began with sharing some information regarding participants' positions, work experiences, knowledge and experiences about Montessori. Then, the mediator introduced the research main questions to stimulate the discussion. Each discussion of each focus group lasted approximately 45 minutes to an hour.

\section{Results:}

The collected qualitative data were analyzed based on the recurring patterns and themes of the focus groups as a whole. Big themes or ideas in the discussion were identified as a category in which deeper discussion followed. As a result, some sub-themes emerged and listed clearly for the participants. Each theme was assigned one letter only out of three possible

\section{2}


letters which are: 1) ' a' to indicate that the item was mentioned and agreed by all participants in the focus groups, 2) 'b' to indicate that the item is positively agreed from the majority of focus groups' members, or 3) 'c' to indicate that there was a negative agreement for the item from the majority of focus groups' members. When there is a 'blank' it means that the challenge was not raised or unfamiliar to the focus group members. The table 2 summarizes the data results.

Table 2:

Summary of the challenges of Montessori implementations in Saudi Arabia

\begin{tabular}{|c|c|c|c|c|c|}
\hline \multicolumn{6}{|l|}{ SA- Groups } \\
\hline Challenges & Educational Context & $\mathrm{SS}$ & SP & ET & $\mathrm{EE}$ \\
\hline \multirow[t]{4}{*}{$\begin{array}{l}\text { Operation of } \\
\text { organization }\end{array}$} & 1. Centrality of decisions & a & a & a & a \\
\hline & 2. Hierarchical order & $\mathrm{b}$ & a & a & a \\
\hline & 3. Complicated procedures & $\mathrm{c}$ & $\mathrm{b}$ & a & a \\
\hline & 4. Lack of clear standards & $\mathrm{c}$ & $\mathrm{b}$ & a & a \\
\hline \multirow[t]{2}{*}{ Vision and philosophy } & 5. absence of practical vision & $\mathrm{b}$ & $\mathrm{b}$ & a & a \\
\hline & 6. absence of Philosophy & $\mathrm{c}$ & $\mathrm{b}$ & a & a \\
\hline \multirow[t]{5}{*}{ Schools' settings } & 7. Schools' buildings & $\mathrm{b}$ & a & a & $\mathrm{b}$ \\
\hline & 8. Schools' facilities & $\mathrm{c}$ & $\mathrm{b}$ & a & $\mathrm{b}$ \\
\hline & 9. Classroom settings & a & a & $\mathrm{b}$ & \\
\hline & 10. Curriculum designs & $\mathrm{c}$ & & a & $\mathrm{c}$ \\
\hline & \multicolumn{5}{|l|}{ Work Ethics and Environment } \\
\hline \multirow[t]{6}{*}{ Work Environment } & 1. Lack of choice & & $\mathrm{a}$ & $\mathrm{a}$ & $\mathrm{a}$ \\
\hline & 2. Lack of support & $\mathrm{c}$ & $\mathrm{b}$ & a & a \\
\hline & 3. Imbalance of duties & $\mathrm{b}$ & $\mathrm{b}$ & & \\
\hline & 4. Issues and conflicts & $\mathrm{b}$ & $\mathrm{b}$ & $\mathrm{c}$ & $\mathrm{c}$ \\
\hline & 5. Level of cooperation & $\mathrm{b}$ & a & a & \\
\hline & \multicolumn{5}{|c|}{ Nature of Teachers and students } \\
\hline $\begin{array}{l}\text { EFL Teachers' } \\
\text { Characteristics }\end{array}$ & 1. Quality of teachers & a & $\mathrm{b}$ & $\mathrm{c}$ & $\mathrm{c}$ \\
\hline
\end{tabular}




\begin{tabular}{|c|c|c|c|c|c|}
\hline & 2. Teachers' preparations & a & $\mathrm{b}$ & $\mathrm{c}$ & a \\
\hline & 3. Lack of training quality & & $\mathrm{b}$ & a & \\
\hline & $\begin{array}{l}\text { 4. Similarity of teaching } \\
\text { methods }\end{array}$ & a & a & a & a \\
\hline \multirow[t]{4}{*}{ Students' attitudes } & 5. Lack of motivation & $\mathrm{b}$ & a & a & $\mathrm{b}$ \\
\hline & 6. Fear and shyness & a & a & a & a \\
\hline & $\begin{array}{l}\text { 7. Unfamiliarity with } \\
\text { cooperative work }\end{array}$ & $\mathrm{b}$ & $\mathrm{a}$ & $\mathrm{a}$ & \\
\hline & \multicolumn{5}{|c|}{ Social and Personal aspects } \\
\hline \multirow[t]{2}{*}{ Language and the Model } & 1. Language barriers & $\mathrm{a}$ & $\mathrm{a}$ & $\mathrm{a}$ & $\mathrm{a}$ \\
\hline & 2. Unfamiliarity with the model & $\mathrm{b}$ & a & a & $\mathbf{a}$ \\
\hline \multirow[t]{2}{*}{ Beliefs and Expectations } & 3. Beliefs about schooling & $\mathrm{b}$ & $\mathrm{b}$ & a & a \\
\hline & $\begin{array}{l}\text { 4. Expectations of leaning } \\
\text { outcomes }\end{array}$ & $\mathrm{b}$ & $a$ & a & $\mathrm{b}$ \\
\hline
\end{tabular}

${ }^{a}$ the item was mentioned and agreed by all participants in the focus groups.

${ }^{\mathrm{b}}$ Positive agreement from the majority of each focus groups' members.

${ }^{\mathrm{c}}$ Negative agreement from the majority of focus groups' members.

As indicated in the above table, the interpretation of data collected by the discussion discourse of the focus groups identified four major categories of challenges for the implementation of the METM in Saudi Arabia which were: 1) the educational context, 2) work ethics and environment, 3) nature of teachers and students, and 4) social and personal aspects. Within each typology, there were some emerging themes and related sub-themes.

Moreover, according to the perspectives of the focus groups, educational context was the one of the major challenges for the implementation of Montessori model in Saudi Arabia. As the sub-themes in table 2 indicate, the educational context was described as central, hieratical, and complicated with no clear standards. The Ministry of Education in Saudi Arabia is in a complete control and in full charge for 
not only making the educational decisions but also setting up regulations, standards, salaries, awards or punishments which all schools and educational institutions must follow.

Absent, or lack, of a clear educational philosophy was an astonishing finding which was agreed upon by all members of the focus groups. English teachers and specialists in particular stressed the fact that the educational philosophy is not known, clear, or even existed. Members of the groups did elaborate more on the side effects of not having a clear philosophy. For instance, a member of the ES group clearly stated that

"Really, it is something implausible not to have a philosophy for our education. Not having one would make everyone do the job based on his personal values and beliefs because it is impossible for anyone to act without having a philosophy or belief of his own."

Moreover, although members of the groups agreed that the classroom settings is indeed a challenge for implementing the METM, they had different views on the curriculum. Whereas SS and ES groups thought that the current English curriculum in Saudi Arabia are good and not a challenge, the ET had different views in which they believed that the current curriculum of English are indeed challenging and not suitable for METM implementation.

Work environment and ethics were also a major challenge to implement the METM in Saudi Arabia. There was nothing so special about the educational work environment in Saudi Arabia which lacks a deeper level of individual choices and group support. From the discourse of the 
discussions, all members of the four focus groups indicated that teachers have indeed limited free choices in regards to materials, curriculum and activities. They have to follow a set of procedures, activities and teaching methods. Any attempt to deviate from the text is not encouraged and in some extreme cases prohibited. English teachers in particular stated that they often feel unfree to be creative and try new things. Members of the ET described this situation saying

\footnotetext{
"Although we are in charge of the learning outcomes, we feel controlled by the curriculum, materials and assessment that we must follow with little, if any, support and guidance. I always hear 'do' and 'don't do' which makes me obligated without a choice."
}

The working environment makes those teachers less creative and more dependent and obliged to follow the roles. The cooperative work was also mentioned as being not the desired degree nor is the norm at work environment.

With the flow of discussion, more topics generated and other doors and windows opened. The quality and competences of English teachers and students were addressed and discussed. It was an interesting finding that the quality of English teachers in Saudi Arabia was rejected as a challenge of implementing METM from all members of the focus group except the supervisors whom they all agreed that the quality of teachers was indeed an issue. The perspectives of SS group was that in order to implement METM in Saudi Arabia, you need to have a certain level of teachers' quality which some current English teachers do not have. 
In addition, the EFL preparation programs was a sub-theme that had different views from the focus groups in which all members of the focus groups shared their concerns about the preparation programs except the English teachers. Most members of the group claimed that the current EFL preparation program were out dated and more rigorous reforms and amendments needed. The ET group viewed the current preparation programs as not a hinder for METM implementation.

Answering the research second question

The last question of the current study was about the differences between the focus groups in regards to the challenges of implementation of METM in Saudi Arabia. With their agreement on the big categories, there were some differences between the groups in the sub-themes. Table 3 shows the main differences and indicates the degree of differences

Table 3:

Comparisons between the focus groups in regards to the challenges

\begin{tabular}{rrrrrr}
\hline & $\begin{array}{r}\text { Challenges } \\
\text { Educational Context }\end{array}$ & SS & SP & ET & EE \\
\hline Organization & 1. Complicated procedures & c & b & a & a \\
& 2. Lack of clear standards & c & b & a & a \\
Vision and philosophy & 3. Absence of practical vision & c & c & a & a \\
& 4. Absence of Philosophy & c & b & a & a \\
Schools' settings & 5. Schools' facilities & c & c & & b \\
Work Environment & 6. Lack of support & c & b & a & a \\
& 7. Issues and conflicts & b & b & c & c \\
EFL Teachers' & 8. Quality of teachers & a & b & c & c \\
Characteristics & 9. Teachers' preparations & a & b & c & a \\
& 10. Lack of motivation & b & a & a & b \\
Students' attitudes & 11. Beliefs about schooling & b & b & a & a \\
Beliefs and Expectations & & & & & \\
\hline
\end{tabular}



outcomes

As indicated in table (2) above, the issues and challenges related to the operation of organization and philosophy got different opinions and views between the study's participants in which members of the SS and SP groups were in one side; whereas, the members of ET and ES were on the other and had another view. On one hand, SS and SP groups showed less agreement that the educational organization in Saudi Arabia was complicated or lacking a clear vision and philosophy. ET and ES groups, on the other hand, fully agreed on the theme that the complication in procedures and lacking a practical vision and philosophy is indeed a big challenge for METM implication. This indicates that there are probably some serious attempts in these regards which the ET and ES were not yet fully aware of, at least at the time of discussion.

In contrast, the lack of students' motivation was a topic that divided members of the focus groups into two sides. Despite the fact that the majority of SS and ES agreed that students' motivation was a potential threat and challenge on one hand, all members of the SP and ET groups, who speak from inside the field, agreed that students' motivation was indeed a challenge which opens an interesting window for further investigation. First hand and everyday experience should indeed be considered.

\section{Discussion}

The current study explored some real challenges for implementing METM in Saudi Arabian elementary schools based on the perspectives of the stakeholders themselves. As the study found, there were some major 
categories of these challenges related to the operation of the organization, work ethics and environment, teachers and students and social lives. It was clear that Montessori principals and philosophy are different from those in the traditional ones as indicated in Ansari \& Winsler's (2014) study who explored some of these differences.

However, the differences in students' achievements between Montessori and tradition are significant and indeed noticeable. Several studies have found that the achievements of Montessori students in several educational levels have been significantly higher and better than their counterparts in the traditional schools (Kayili \& Ari, 2011; McDurham, 2011; and Lillard, 2012).

Moreover, it was clear from the discourse of the focus groups discussion that although they all shared the view that challenges of METM implementation in Saudi Arabia existed, but they had a little different view on sub-themes of those challenges. The type of EFL teachers' preparation programs and the similarity of instruction were just some of the challenges which were in line with the findings of other recent studies such as Christensen (2018) and Lillard (2018).

However, it seems that the educational positions of the members of the focus groups impacted their stands on some of these challenges. They agreed on the fact that some challenges lead to the next and the bigger the challenge is the more difficult to overcome. In addition, it was indicated in the discourse that immediate remedial procedures are needed to minimize or completely overcome those challenges. Further and deeper investigation on the topic is needed as to explore some possible ways for remedial steps, 
actions, and procedures. It would also be worth studying to investigate the differences in academic achievements between Montessori and traditional schools.

Moreover, lack of support and the existence of conflicts were also some challenges that the members have different views on them. In fact, these sub-themes have opposite sides. As for lack of support, unlike the SS and SP, ET and ES agreed completely that there were some lack of support, but coming to the existence of conflicts, the positions was reverse. This might be an indicator of the nature of the work ethics in which the upper positions the member was, the more conflicts and issues arouse due to competence and having different perspectives.

\section{Conclusion:}

Montessori English teaching model presents some valuable approaches to education and English teaching and learning. However, METM is still unknown or even practiced in Saudi Arabia. METM could provide a way to improve Saudi students' English proficiency significantly.

Moreover, the current study added to the current knowledge and investigation of the impacts of Montessori models on schools and achievements. Young students' intensity of growth might be a reason for the complexity of teaching and learning which, as a result, might become a reason for getting a relatively lower academic achievements than expected. Upon uncovering some real challenges of implementing METM in Saudi Arabian education, some rigorous and serious reforms should take place in Saudi Arabian elementary schools for the sake of the future of students, nation and society. 
مجلة دراسات في المناهج وطرق التدريس، الترقيم الدولي (ISSN 2535-213X)/ العدد 245 (2019م)

\section{REFERENCES}

Al Shlowiy, A. (2014). Lifting Motivation Level of English Learners in Saudi Arabia. Arab World English Journal, 5 (1), 129-136.

Al-Shumaimeri, Y. (2003). A study of classroom exposure to oral pedagogic tasks in relation to the motivation and performance of Saudi secondary learners of English in a context of potential curriculum reform. Unpublished Ph.D. Thesis, University of Leeds, Leeds.

Author, W. (2019). Bridging the gaps: EFL teacher preparation programs A study in Saudi Arabian Context. The Journal of Educational Psychological Sciences 32, (3), 168-184.

American Montessori Society (2018). Inside the Montessori Classroom. Retrieved on Nov. 26, 2017, from hppt:// https://amshq.org/AboutMontessori/Inside-the-Montessori-Classroom.

Ansari, A., Winsler, A. (2014). Montessori Public School Pre-K Programs and the School Readiness of Low-Income Black and Latino Children. Journal of Educational Psychology (106), 4, 1066-1079.

Ashraf, T. (2018). Teaching English as a Foreign Language in Saudi Arabia: Struggles and Strategies. International Journal of English Language Education 6, (1), 133-149, doi: 10.5296/ijele.v6i1.13148.

Beyea, S., \& Nicoll, L. H. (2000). "Learn more using focus groups." AORN, 71 (4), 897-900.

Christensen, O. (2018). Transforming the Transformation: A postintentional phenomenological exploration of Montessori teachers engaging in anti-bias and anti-racist teacher self-reflection. Unpublished Dissertation. University of Minnesota.

Cossentino, J. (2009). Culture, Craft, \& Coherence: The Unexpected Vitality of 
مجلة دراسات في المناهج وطرق التدريس، الترقيم الدولي (ISSN 2535-213X)/ العدد 245 (2019م)

Montessori Teacher Training. Journal of Teacher Education 60 (5), $520-527$.

Dearing, E., McCartney, K., \& Taylor, B. A. (2009). Does higher quality early child care promote low-income children's math and reading achievement in middle childhood? Child Development, 80, 1329-1349.

Dohrmann, K. R., Nishida, T. K., Gartner, A., Lipsky, D. K., \& Grimm, K.( 2007). High school outcomes for students in a public Montessori program. Journal of Research in Childhood Education, 22, 205-217.

Duckworth, C. (2006). Teaching peace: a dialogue on the Montessori Method.Journal of Peace Education, 3 (1), 39-53. https://doi.org/10.1080/17400200500532128

Ghaffari, M., Kashkouli, S., \& Sadighi, F. (2017). Montessori and conventional teaching methods in learning English as a second/foreign language: An overview. Journal of Applied Linguistics and Language Research, 4 (5), 209- 218. Retrieved from:

http://jallr.com/index.php/JALLR/article/view/657/pdf657

Gutek, G. (2004). The Montessori Method: The origins of an educational innovation: Including an abridged and annotated edition of Maria Montessori's the Montessori Method. Lanham, MD: Rowman \& Littlefield Publishers.

Goodenow, C. "Classroom Belonging among Early Adolescent Students: Relationships to Motivation and Achievement." Journal of Early Adolescence 13 (1993), 21- 43.

Hainstock, E. (1997). The Essential Montessori: An Introduction to the women, the Writings, the method, and the movement. New York: Plume printing. 
مجلة دراسات في المناهج وطرق التدريس، الترقيم الدولي (ISSN 2535-213X)/ العدد 245 (2019م)

Kayili, G., \& Ari, R. (2011). Examination of the effects of the Montessori Method on Preschool children's readiness to primary education.

Educational Sciences: Theory and Practice, 11, 2104-2109.

Kay1l1, G. (2018). The effect of the Montessori Method on the cognitive tempo of Kindergarten children. Early Child Development and Care, 188 (3), 327-335 Retrieved from: https://doi.org/10.1080/03004430.2016.1217849

Kuh G. (2009). What student affairs professionals need to know about students' Engagement? Journal of College Student Development 50, 683706.

Krueger, R. A., and Casey, M. A. (2000). Focus groups: A practical guide for applied research, $3 r d$ Ed. SAGE Publications, Thousand Oaks, CA.

Lightbown, P. M., \& Spada, N. (2013). How languages are learned 4th edition- Oxford Handbooks for Language Teachers. Oxford, England: OxfordUniversity Press.

Lillard, A. (2012). Preschool children's development in classic Montessori, supplemented Montessori, and conventional programs. Journal of School Psychology, 50, 379-401.

Lillard, A., \& Else-Quest, N. (2015). The early years: Evaluating Montessori education. Science, 313, 1893-1894.

Lillard, A. S. (2013). Playful learning and Montessori education. American Journal of Play, 5 (2), 157-186.

Lopata, C., Wallace, N. \& Finn, K. (2005). Comparison of academic achievement between Montessori and traditional education programs. Journal of Research in Childhood Education, 20, 5-13. 
مجلة دراسات في المناهج وطرق التدريس، الترقيم الدولي (ISSN 2535-213X)/ العدد 245 (2019م)

Marshall, C. (2017). Montessori education: a review of the evidence base. npj Science of Learning 2 (11 ). doi:10.1038/s41539-017-0012-7

McDurham, R. (2011). A Comparison of Academic Achievement for Seventh and Eighth Grade Students from Montessori and Non-Montessori School Programs. Unpublished Dissertation. Tarleton State University. Mckenzie, G. (2007). Montessori secondary schools; preparing today's adolescents for the challenges of tomorrow. Montessori Life (4), 26-32. Montessori, M. (1949). The absorbent mind. Adyar, Madras, India: The Theosophical Publishing House.

Pickering, J. S. (1992). Successful applications of Montessori methods with children at risk for learning disabilities. Annals of Dyslexia, 42, 90109.

Ryniker, D. H., \& Shoho, A. R. (2001). Student perceptions of their elementary classrooms: Montessori vs. traditional environments. Montessori Life, winter, 45-48.

Rathunde, K., \& Csikszentmihalyi, M. (2005). The Social Context of Middle School:Teachers, Friends, and Activities in Montessori and Traditional School Environments. The Elementary School Journal, 106 (1), 59- 79. Doi:10.1086/496907.

Rathunde, K., \& Csikszentmihalyi, M. (2005). Middle school students' motivation and quality of experience: A comparison of Montessori and traditional school environments. American Journal of Education, 111, 341-371. 
مجلة دراسات في المناهج وطرق التريس، الترقيم الدولي (ISSN 2535-213X)/ العدد 245 (2019م)

Seldin, T. (2002/03). What research says about Montessori's

effectiveness? Tomorrow's Child Magazine, Winter, 5-11.

Stapleton, T. J. (2014). Multi-sensory, hands-on manipulatives, and adult ESL. NAMTA Journal, 39 (3), 153-169.

Tracy, S., Lutgen-Sandvik, P., \& Alberts, J. (2006). "Nightmares, demons, and slaves:Exploring the plainful metaphors of workplace bullying." Manage Commun. Q., 20 (2), 148-185

Vandell, D. , Belsky, J., Burchinal, M., Steinberg, L., Vandergrift, N., \& NICHD

Early Child Care Research Network. (2010). Do effects of early child care extend to age 15 years? Results from the NICHD study of early child care and youth development. Child Development, 81, 737-756. 